\title{
Propolis increases neuronal count in hippocampal area CA1 and prefrontal cortex in stressed rats
}

\author{
Kuswati*, Ety Sari Handayani*, and Zainuri Sabta Nugraha*
}

\begin{tabular}{l}
\hline \\
\hline \\
*Department of Anatomy, \\
Faculty of Medicine, \\
Islamic University of Indonesia \\
Yogyakarta \\
Correspondence \\
dr. Kuswati, M.Sc \\
Department of Anatomy, \\
Faculty of Medicine, \\
Islamic University of Indonesia \\
Jl. Kaliurang km 14,5 Yogyakarta \\
Phone: +62274 898444 \\
Mobile: +62 852 284 78487 \\
Email : kuswatinugroho@gmail.com
\end{tabular}

Date of first submission, July 26, 2017

Date of final revised submission,

November 22, 2017

Date of acceptance, November 22,

2017

This open access article is distributed under a Creative Commons AttributionNon Commercial-Share Alike 4.0 International License

Cite this article as: Kuswati, Handayani ES, Nugraha ZS. Propolis increases neuronal count in hippocampal area CA1 and prefrontal cortex in stressed rats. Univ Med 2017;36:214-20. doi: 10.18051/UnivMed.2017.v36.214220

\section{BACKGROUND}

Stress induces neuronal cell damage in the hippocampus and prefrontal cortex. Propolis has a neuroprotective effect that can inhibit apoptosis and decrease neuronal cell count. This study aimed to determine the effect of propolis on neuronal cell count in hippocampal area CA1 and prefrontal cortex in Sprague Dawley rats with induced stress.

\section{METHODS}

A study of laboratory experimental design was conducted involving 24 male Sprague-Dawley Rattus norvegicus. The animals were randomly divided into 4 groups, i.e. controls (K), and stress groups P1, P2 and P3. Controls did not receive treatment, stress group $(\mathrm{P} 1)$ received stress treatment, groups P2 and P3 received stress and propolis at 100 and 200 $\mathrm{mg} / \mathrm{kgBW}$, respectively. Stress and propolis were given for 14 days, followed by termination. The number of neurons in the hippocampal area CA1 and prefrontal cortex were counted. One way ANOVA was used to analyze the data.

\section{RESULTS}

The neuronal count in the hippocampal area CA1 and prefrontal cortex in the stress group (P1) was lower than in groups K, P2 and P3. There were significant differences in the neuronal count of the hippocampal area CA1 between $\mathrm{P} 1$ and $\mathrm{P} 3$ and $\mathrm{P} 1$ and $\mathrm{K}(\mathrm{p}=0.019)$ and also in the neuronal count of the prefrontal cortex between P1 and P2, P3 and K ( $\mathrm{p}=0.002)$.

\section{CONCLUSIONS}

This study strongly suggest that propolis inhibits the decrease in neuronal count in in the hippocampal area CA1 and prefrontal cortex of Sprague Dawley rats with induced stress. The present study suggests a potential neuroprotective effect of propolis in the prevention of neurodegenerative disorders.

Keywords: Propolis, hippocampus, prefrontal cortex, stress, rats 


\section{INTRODUCTION}

The hippocampus plays an important role in learning and memory and is one of the brain regions that is affected by stress. ${ }^{(1)}$ Rats treated with various chronic stress models, by reducing sleep duration, immobilization stress and electrical stress, have a lower number of pyramidal cells in area $\mathrm{CA} 3$ of the hippocampus than do rats without stress treatment. ${ }^{(2)}$ Stress administered to rats 6 hours daily for 6 weeks results in changes in the hippocampal neurons. These changes comprise a reduction in the number and length of apical and basal dendrites, so causing atrophy of the neurons in area CA3 of the hippocampus. ${ }^{(3)}$ Chronic stress plays a role in the aging process in the hippocampus, marked by changes in the expression of several genes. Exposure to stress for 10 days decreases the gene expression levels of sirtuin-1 and heat shock protein 70 , but increases the gene expression levels of P-53, thioredoxin-interacting protein and nicotinamide adenine dinucleotide phosphate (NADPH) oxidase. ${ }^{(4)}$

In the prefrontal cortex, chronic stress increases the noradrenergic innervation and causes a decrease in working memory and interference with the connections between the prefrontal cortex and the hippocampus. ${ }^{(5)}$ Stress results in a decrease in the number of neurons (neuronal cell count) and B cell lymphoma 2 (Bcl2 ) expression in the prefrontal cortex. ${ }^{(6,7)}$ The combination of acute and chronic stress results in cytochrome $\mathrm{C}$ release from the mitochondria into the cytoplasm, activation of caspase- 3 and increase in the number of cells undergoing apoptosis in the prefrontal cortex. ${ }^{(8)}$ The results of the study by Li et al. ${ }^{(9)}$ demonstrates the occurrence of apoptosis and changes in the Bcl2 associated $\mathrm{X}(\mathrm{Bax})$ and the $\mathrm{Bcl}-2 / \mathrm{Bax}$ ratio in the prefrontal cortex of rat models of post traumatic stress disorder (PTSD). Bachis et al. ${ }^{(10)}$ report an increase in the number of cells expressing caspase 3 in the pyramidal frontal cortex layers of Sprague Dawley rats undergoing stress. Rats that were given stress treatment by chronic social isolation for 6 weeks underwent an increase in apoptosis, a decrease in Bcl-2 protein, an increase in Bax, and an increase in the $\mathrm{Bax} / \mathrm{Bcl}-2$ ratio in the prefrontal cortex. ${ }^{(11,12)}$ Cao et al. ${ }^{(13)}$ report that socially isolated rats have spatial and short term memory dysfunction, abnormal social functioning and anxiety. In addition, there was also increased active caspase 3 expression in the medial prefrontal cortex and hippocampus.

Propolis is one of the substances that are expected to be able to protect neurons from damage due to stress exposure. ${ }^{(14)}$ Propolis contains chrysin, caffeic acid phenethyl ester (CAPE) and caffeoylquinic acid (CQA) that have neuroprotective effects. ${ }^{(15,16)}$ Previous studies have proven that propolis may inhibit apoptosis in cell cultures of SH-SY5Y neurons (a human neuroblastoma cell line) that were exposed to staurosporin, by inhibiting caspase- 3 activity and apoptosis through the intrinsic pathway. ${ }^{(17)}$ The aqueous extract of propolis decreases the production of lactate dehydrogenase (LDH) in cultures of the PC12 pheochromocytoma cell line as a result of exposure to $\mathrm{H}_{2} \mathrm{O}_{2}$. This shows that the aqueous extract of propolis has protective effects on the mitochondria and cell membranes of neurons. ${ }^{(18)}$ Pinocembrin is one of the flavanones found in propolis and honey with actions useful in preserving cognitive function. ${ }^{(19)}$ In a recent animal study, pinocembrin ameliorated cerebral damage caused by global cerebral ischemia-reperfusion. ${ }^{(20)}$ These neuroprotective effects were attributed to pinocembrin suppressing damaging biomarkers including oxidative stress and inflammation.

One study found that Chinese propolis inhibits neuronal cell death induced by endoplasmic reticulum stress that has been implicated in the pathogenesis of neurodegenerative and ischemic disorders. ${ }^{(17)}$ Long term administration of chrysin at $30 \mathrm{mg} / \mathrm{kg}$ showed reduced pathological changes and attenuated the chronic cerebral hypoperfusion induced cell loss in the cortex and hippocampal CA1 area of rats. ${ }^{(21)}$ However, there is no 
information available on the effect of propolis administration on the neuronal cell count in the hippocampal and prefrontal cortex areas.

The present study aimed to evaluate the effect of propolis administration on the neuronal cell counts in the hippocampal area CA1 and the prefrontal cortex in Sprague Dawley rats receiving social isolation stress exposure.

\section{METHODS}

\section{Research design}

This was an experimental laboratory study with posttest only control group design. The study was conducted at the Research Laboratory, Faculty of Medicine, Universitas Islam Indonesia (FK UII) from March to December 2016.

\section{Research subjects}

The study subjects were 4 month-old male Rattus norvegicus of the Sprague -Dawley strain, weighing 200-300 grams. The number of subjects required were calculated with the formula of Charan and Biswas ${ }^{(22)}$ as follows: $\mathrm{E}=$ total number of animals - total number of groups $=10-20$

Total number of animals $=20$ - total number of groups $=20-4=16$

From the above calculation the number of subjects obtained was 16 rats. This method of sample size calculation is rather crude and should only be used if it cannot be done by power analysis. All experiments were performed in accordance with the standard guidelines for the care and use of laboratory animals.

\section{Preparation of propolis extract}

The propolis preparation used in this study is a product available in the free market, with 1 $\mathrm{ml}$ containing $600 \mathrm{mg}$ propolis. To $0.1 \mathrm{ml}$ of the propolis preparation $0.9 \mathrm{ml}$ distilled water was added thus giving a concentration of $60 \mathrm{mg} / \mathrm{ml}$. This dilution was used to make up doses of 100 $\mathrm{mg} / \mathrm{kgBW}$ and $200 \mathrm{mg} / \mathrm{kgBW}$ to be administered to the rats, in accordance with the study of Lee et al. ${ }^{(23)}$

\section{Stress procedure and propolis treatment}

In this study the social isolation stress model was applied by holding one rat per cage so that there was no interaction with the other rats. ${ }^{(24)}$ This stress treatment was given for 14 days. The rats were divided by block randomization into 4 groups, each consisting of 4 rats $(n=4)$. The groups comprised one control group (K), one stress group (P1) and two propolis groups ( $\mathrm{P} 2$ and $\mathrm{P} 3)$. The control group did not receive treatment, the stress group (P1) received stress treatment, while groups $\mathrm{P} 2$ and $\mathrm{P} 3$ received stress treatment and oral propolis administration by gastric tube at doses of 100 and $200 \mathrm{mg} / \mathrm{kgBW}$, respectively. The control group and the stress group (P1) received distilled water.

\section{Sample preparation}

On day 15 the rats were terminated and underwent transcardial perfusion. The rats were anesthesized by an intramuscular injection of ketamine at $100 \mathrm{mg} / \mathrm{kgBW}$. The transcardial perfusion used normal saline at 100-200 ml until the returning perfusion fluid was clear. After perfusion, the brain was carefully dissected out and the portions containing the hippocampus and the prefrontal cortex were fixed in phosphatebuffered formalin for 24 hours.

The portions of the brain containing the hippocampus and the prefrontal cortex were made into paraffin blocks and sectioned at $4 \mu \mathrm{m}$. The sectioning was done at the portion containing the hippocampus. From one rat brain 3 sample sections were made at distances of $240 \mu \mathrm{m}$.

Hematoxyllin eosin staining was done according to the protocol at the Research Laboratory of FK UII, which briefly was as follows. The slide containing the tissue section was placed in a staining jar, deparaffinized, then washed twice in distilled water. Subsequently the slide was placed in the hematoxyllin solution for 10 minutes, washed 3 times in distilled water, and checked under the microscope. If the hematoxyllin staining was adequate, the slide was washed in running water. Subsequently the 
Table 1. Distribution of mean neuronal cell counts in hippocampal area CA1 and in the prefrontal cortex, by treatment groups

\begin{tabular}{lccccc}
\hline \multirow{2}{*}{ Variable } & \multicolumn{4}{c}{ Treatment groups } & p value \\
\cline { 2 - 5 } & $\mathbf{K}(\mathbf{n}=\mathbf{4})$ & $\mathbf{P 1}(\mathbf{n}=\mathbf{4})$ & $\mathbf{P 2}(\mathbf{n}=\mathbf{4})$ & $\mathbf{P 3}(\mathbf{n}=\mathbf{4})$ & 0.019 \\
\hline $\begin{array}{l}\text { Neuronal cell count of } \\
\text { hippocampal area CA1 }\end{array}$ & $61.69 \pm 9.89$ & $40.08 \pm 2.59$ & $51.86 \pm 11.11$ & $58.49 \pm 14.61$ & 0.021 \\
$\begin{array}{l}\text { Neuronal cell count of } \\
\text { prefrontal cortex }\end{array}$ & $86.80 \pm 14.50$ & $50.03 \pm 4.76$ & $88.11 \pm 22.44$ & $89.63 \pm 21.55$ & 0.021 \\
\hline
\end{tabular}

$\mathrm{K}=$ control group (non-stress); $\mathrm{P} 1=$ stress group; $\mathrm{P} 2=$ stress group + propolis $100 \mathrm{mg} / \mathrm{kgBW}$; $\mathrm{P}$ =stress group + propolis 200 $\mathrm{mg} / \mathrm{kgBW}$

preparation was placed in eosin and washed twice in distilled water. The slide was placed in the alcohol series of $70 \%, 80 \%, 90 \%, 95 \%$, and $100 \%$ then dried with tissue paper. The dried slide was placed in xylol I, II and III for 5 minutes each, then mounted and observed under the microscope.

\section{Neuronal cell counts in hippocampus and prefrontal cortex}

The preparation was observed under the light microscope at $400 \mathrm{x}$ magnification. The cell count was performed in the whole hippocampal area CA1 and prefrontal cortex. Subsequently the mean number of cells was calculated for one preparation per field of view with the formula: Mean cell count $=$ number of cells in the area under observation/number of fields of view.

\section{Data analysis}

To compare the mean cell count per field of view between the groups, one-way ANOVA was used, followed by a post hoc test to determine the differing groups. A p-value of less than 0.05 was considered statistically significant.

\section{Ethical clearance}

This study was approved by the Research Ethics Committee, Faculty of Medicine, Universitas Islam Indonesia under No. 03/ Ka.Kom.Et/70/KE/V/2016.

\section{RESULTS}

The resulting neuronal cell counts in hippocampal area CA1 and prefrontal cortex are presented in Table 1. The results of one way ANOVA showed a significant difference in neuronal cell count of hippocampal area CA1 between the four groups $(p=0.019)$. The results of post hoc analysis showed significant differences between group P1 and the control group and group P3, respectively (Table 2). Significant differences in neuronal cell counts were also found in the prefrontal cortex $(\mathrm{p}=0.021)$. The results of post hoc analysis showed significant differences between group P1 and the groups K, $\mathrm{P} 2$ and $\mathrm{P} 3$, respectively (Table 3 ). There were no significant differences between the control group $\mathrm{K}$ and groups $\mathrm{P} 2$ and $\mathrm{P} 3$.

Table 2. Results of post hoc analysis of mean neuronal cell counts of hippocampal CA1

\begin{tabular}{ccc}
\hline Group & Group & p value \\
\hline $\mathrm{K}$ & $\mathrm{P} 1$ & 0.003 \\
& $\mathrm{P} 2$ & 0.139 \\
& $\mathrm{P} 3$ & 0.620 \\
$\mathrm{P} 1$ & $\mathrm{P} 2$ & 0.093 \\
& $\mathrm{P} 3$ & 0.013 \\
$\mathrm{P} 2$ & $\mathrm{P} 3$ & 0.331 \\
\hline
\end{tabular}

$\mathrm{K}=$ control group (non-stress); $\mathrm{P} 1=$ stress group; $\mathrm{P} 2=$ stress group + propolis $100 \mathrm{mg} / \mathrm{kgBW} ; \mathrm{P} 3=$ stress group + propolis $200 \mathrm{mg} / \mathrm{kgBW}$

Table 3. Results of post hoc analysis of mean neuronal cell counts of prefrontal cortex

\begin{tabular}{ccc}
\hline Group & Group & p value \\
\hline $\mathrm{K}$ & $\mathrm{P} 1$ & 0.001 \\
& $\mathrm{P} 2$ & 0.898 \\
& $\mathrm{P} 3$ & 0.783 \\
$\mathrm{P} 1$ & $\mathrm{P} 2$ & 0.001 \\
& $\mathrm{P} 3$ & 0.001 \\
$\mathrm{P} 2$ & $\mathrm{P} 3$ & 0.898 \\
\hline
\end{tabular}

$\mathrm{K}=$ control group (non-stress); $\mathrm{P} 1=$ stress group; $\mathrm{P} 2=$ stress group + propolis $100 \mathrm{mg} / \mathrm{kgBW} ; \mathrm{P} 3=$ stress group + propolis $200 \mathrm{mg} / \mathrm{kgBW}$ 


\section{DISCUSSION}

The results of this study showed that in the stress groups receiving propolis treatment $(\mathrm{P} 2$ and P3) the mean neuronal cell counts were higher than in the stress group receiving distilled water (P1). This showed that propolis treatment may inhibit the decrease in neuronal cell counts in hippocampal area CA1 and prefrontal cortex as a result of stress exposure. One study evaluated the effect of administration of propolis and caffeic acid phenylethyl ester (CAPE) on brain tissue of rats exposed to ionizing radiation and showed that propolis and CAPE would reduce the oxidative damage in the radiation-injured brain tissue. ${ }^{(25)}$

The results of the study by Reis et al. ${ }^{(26)}$ showed that supplementation with oil extract of propolis (OEP) at doses of 10, 30 and $50 \mathrm{mg} /$ $\mathrm{kgBW}$ administered intraperitoneally for 1 hour produced anxiolytic and antidepressant effects and improved locomotion in rats. Another study showed that an aqueous extract of propolis decreased the production of LDH in cultures of neuronal-like PC12 cells as a result of exposure to $\mathrm{H}_{2} \mathrm{O}_{2} \cdot{ }^{(18)}$ This showed that aqueous extract of propolis has protective effects on mitochondria and neuronal cell membranes. In mice with scopolamine-induced neurotoxicity, administration of propolis at $100 \mathrm{mg} / \mathrm{kgBW}$ may improve memory, and inhibit acetylcholine esterase activity in the cerebral and hippocampal cortex. ${ }^{(27)}$ This showed that propolis increased memory through inhibition of acetylcholine esterase activity in the hippocampus. Therefore, propolis has the pharmacologic potential of a neuroprotective agent and may be used for treatment of amnesia in the elderly, Alzheimer's disease (AD) and other neurodegenerative diseases.

Propolis administration at a dose of $200 \mathrm{mg} /$ $\mathrm{kgBW}$ to Wistar rats exposed to aluminum nitrate could inhibit lipid peroxidation in the liver, kidneys and neurons. ${ }^{(28)}$ Furthermore, propolis treatment could increase the concentrations of the antioxidant glutathione in brain tissues. Propolis treatment could inhibit the decrease in ATPase in the liver, kidneys and brain. Propolis treatment could restore acetylcholine esterase activity in the brain after exposure to aluminum nitrate. Addition of an ethanolic extract of propolis to neuronal cell cultures which had been exposed to the neurotoxic agents staurosporin and hydrogen peroxide, could inhibit the production of reactive oxygen species (ROS) and caspase3 activity. ${ }^{(29)}$ In rats with neurotoxicity induced by exposure to lead $(\mathrm{Pb})$ for 4 weeks and receiving oral propolis treatment, it was shown that propolis could inhibit the neurotoxic effects of $\mathrm{Pb}$. This was apparent in the normal acetylcholine esterase activity and the decrease in malondialdehyde (MDA) concentrations in the brain. Propolis increased the activities of reduced nicotinamide adenine dinucleotide (NADH), succinate dehydrogenase (SDH) and cytochrome C oxidase in mitochondria. ${ }^{(30)}$

Propolis contains CAPE that has been proven to have neuroprotective effects. CAPE inhibits neurodegeneration in dopaminergic neurons in the striatum and prevents the loss of dopamine in the 1-methyl-4-phenyl-1,2,3,6tetrahydropyridine (MPTP) mouse model of Parkinson's disease. The neuroprotective effect of CAPE is associated with decreased inducible nitric oxide synthase (iNOS) and caspase 1 expression. In vitro, CAPE inhibits the neurotoxicity induced by $\mathrm{MPP}^{+}$(1-methyl-4phenylpyridinium), the neurotoxic oxidation product of MPTP, and inhibits the release of cytochrome $\mathrm{C}$ and apoptosis inducing factor (AIF) from the mitochondria. ${ }^{(15)} \mathrm{CAPE}$ reduces the neurotoxicity due to acrolein in HT22 murine hippocampal neuronal cells. CAPE inhibits ROS production by neuronal cells of the hippocampus as a result of acrolein exposure. Therefore, CAPE has antioxidant effects. Administration of CAPE restores decreased glutathione levels from acrolein exposure in hippocampal neuronal cultures. CAPE inhibits the activation of $\mathrm{p} 38$ and JNK. ${ }^{(31)}$

Propolis contains caffeoylquinic acid (CQA), an antioxidant component with neuroprotective effect in cultures of 1-42 
treated SH-SY5Y neuroblastoma cells. CQA increases the viability of $1-42$ cells treated with SH-SY5Y. CQA increases the expression of glycolytic enzyme mRNA (phosphoglycerate kinase-1; PGK1) and intracellular ATP concentrations. CQA improves spatial learning and memory in mice. ${ }^{(16)}$

Chrysin decreases the activities of superoxide dismutase and lipid peroxidase, and the levels of nitric oxide, tumor necrosis factor alpha, and interleukin-1 $\beta$. Administration of chrysin inhibits the expression of Bax, Bcl-2 and caspase-3. ${ }^{(32)}$

The limitation of the present study is that only a histological examination was performed with counting of the number of neuronal cells in the brain and no biochemical analysis that may support the results of this study. The clinical implication of these study results is that propolis may be used to inhibit or prevent neuronal damage due to degeneration caused by stress exposure. Further studies should be done to study the pharmacologic effects and the toxicity of propolis in order to support its benefits as a neuroprotective agent in brain tissue.

\section{CONCLUSION}

Administration of propolis may inhibit a decrease in neuronal cell count in hippocampal area $\mathrm{CA} 1$ and prefrontal cortex in rats with social isolation-induced stress. This study provides useful information for considering propolis as an alternative treatment choice for neurode generative disorders.

\section{CONFLICT OF INTEREST}

There were no conflicts of interest in the present study.

\section{ACKNOWLEDGMENT}

The authors express their gratitude to the Research and Community Service Unit, Faculty of Medicine, Islamic University of Indonesia, who provided the funds for this study on hippocampal area CA1 through the lecturer grant scheme (skema hibah dosen). They also thank the Directorate for Research and Community Service, Universitas Islam Indonesia, for the funds to conduct the study on the prefrontal cortex through the starting lecturer grant scheme (skema hibah dosen pemula).

\section{CONTRIBUTORS}

$\mathrm{K}$ contributed to the design of the study, wrote the protocol and wrote the first draft of the manuscript. ZSN contributed to revising the protocol. ESH revised the manuscript. All authors read and approved the final manuscript.

\section{REFERENCES}

1. Kim EJ, Pellman B, Kim JJ. Stress effects on the hippocampus: a critical review. Learn Mem 2015; 22:411-6.

2. Fitranto A, Soejono SK, Maurits LS, et al. Jumlah sel piramidal CA3 hippocampus tikus putih jantan pada berbagai model stres kerja kronik. MKB 2014;46:197-202.

3. Hemmalini, Rao S. Anti stress effect of Centella asiatica leaf extract on hippocampal CA3 neurons - a quantitative study. Int J Pharmacol Clin Sci 2013;2:25-32.

4. Hidalgo ACS, Munoz MF, Herrera AJ, et al. Chronic stress alters the expression levels of longevity-related genes in the rat hippocampus. Neurochem Int 2016;97:181-92.

5. Arnsten AFT. Stress signalling pathways that impair prefrontal cortex structure and function. Nat Rev Neurosci 2009;10:410-22.

6. Kuswati, Prakosa D, Wasita B, et al. Centella asiatica increases B-cell lymphoma 2 in rat prefrontal cortex. Univ Med 2015;34:10-6.

7. Priyantiningrum AK, Kuswati, Handayani ES. Pengaruh ekstrak etanol Centella asiatica terhadap jumlah sel neuron di cortex prefrontalis tikus yang diberi perlakuan stres. JKKI 2015;6:198204.

8. Filipovic D, Zlatkovic J, Inta D, et al. Chronic isolation stress predisposes the frontal cortex but not the hippocampus to the potentially detrimental release of cytochrome $\mathrm{c}$ from mitochondria and the activation of caspase-3. J Neurosci Res 2011;89:1461-70. 
9. Li Y, Han F, Shi Y. Increased neuronal apoptosis in medial prefrontal cortex is accompanied with changes of Bcl-2 and Bax in a rat model of posttraumatic stress disorder. J Mol Neurosci 2013;51: 127-37.

10. Bachis A, Cruz MI, Nosheny, RL, et al. Chronic unpredictable stress promotes neuronal apoptosis in the cerebral cortex. Neurosci Lett 2008;442:104-8.

11. Djorjevic A, Adzic M, Djorjevic J, et al. Chronic social isolation suppresses proplastic response and promotes proapoptotic signaling in prefrontal cortex of wistar rats. J. Neurosci Res 2010;88:252433.

12. Djorjevic A, Djorjevic J, Elakovic I, et al. Effect of fluoxetine on plasticity and apoptosis evoked by chronic stress in rat prefrontal cortex. Eur $\mathrm{J}$ Pharmacol 2012;693:37-44.

13. Cao $\mathrm{M}, \mathrm{Pu} \mathrm{T}$, Wang $\mathrm{L}$, et al. Early enriched physical environment reverses impairments of the hippocampus, but not medial prefrontal cortex of socially-isolated mice. Brain Behav Immun 2017; 64:232-3.

14. de Menezes da Silveira CCS, Fernandes LMP, Silva ML, et al. Neurobehavioral and antioxidant effects of ethanolic extract of yellow propolis. Oxidative Med Cell Longevity 2016, Article ID 2906953, 14 pages.

15. Fontanilla CV, Ma Z, Wei X, et al. Caffeic acid phenethylester prevents 1-methyl-4-phenyl$1,2,3,6$-tetrahydropyridine-induced neurodegeneration. Neuroscience 2011;188:13541.

16. Han J, Miyamae Y, Shigemori H, et al. Neuroprotective effect of 3,5-di-O-caffeoylquinic acid on SH-SY5Y cells and senescenceaccelerated-prone mice 8 through the upregulation of phosphoglycerate kinase-1. Neuroscience 2010;169:1039-45.

17. Izuta H, Shimazawa M, Tazawa S, et al. Protective effects of Chinese propolis and its component, chrysin, against neuronal cell death via inhibition of mitochondrial apoptosis pathway in SH-SY5Y cells. J Agrict Food Chem 2008;56:8944-53.

18. Jeong CH, Jeong HR, Kim DO, et al. Phenolics of propolis and in vitro protective effects against oxidative stress induced cytotoxicity. J Agric Life Sci 2012;46:87-95.

19. Kure C, Timmer J, Stough C. The immunomodulatory effects of plant extracts and plant secondary metabolites on chronic neuroinflammation and cognitive aging: a mechanistic and empirical review. Front Pharmacol 2017;8:117.
20. Saad MA, Abdel Salam RM, Kenawy SA, et al. Pinocembrin attenuates hippocampal inflammation, oxidative perturbations and apoptosis in a rat model of global cerebral ischemia reperfusion. Pharmacol Rep 2015;67: 115-22.

21. He XL, Wang YH, Bi MG, et al. Chrysin improves cognitive deficits and brain damage induced by chronic cerebral hypoperfusion in rats. Eur $\mathrm{J}$ Pharmacol 2012;680:41-8.

22. Charan J, Biswas T. How to calculate sample size for different study designs in medical research? Indian J Psychol Med 2013;35:121-6.

23. Lee MS, Kim YH, Park WS. Novel antidepressantlike activity of propolis extract mediated by enhanced glucocorticoid receptor function in the hippocampus. Evidence-Based Complementary Altern Med 2013, Article ID 646039, 10 pages.

24. Zlatkovic J, Filipovic D. Bax and B-cell-lymphoma 2 mediate proapoptotic signaling following chronic isolation stress in rat brain. Neuroscience 2012;223:238-45.

25. Alkis HE, Kuzhan A, Dirier A, et al. Neuroprotective effects of propolis and caffeic acid phenethyl ester on the radiation-injured brain tissue. Intern J Radiat Res 2015;3:297-303.

26. Reis JSS, Oliveira GB, Monteiro MC, et al. Antidepressant- and anxiolytic-like activities of an oil extract of propolis in rats. Phytomedicine 2014;21:466-72.

27. Chen J, Long Y, Han M, et al. Water-soluble derivative of propolis mitigates scopolamineinduced learning and memory impairment in mice. Pharmacol Biochem Behav 2008;90:441-6.

28. Bhadauria M. Combined treatment of HEDTA and propolis prevents aluminum induced toxicity in rats. Food Chem Toxicol 2012;50:2487-95.

29. Cardoso SM, Ribeiro M, Ferreira IL, et al. Northeast Portuguese propolis protects against staurosporine and hydrogen peroxide-induced neurotoxicity in primary cortical neurons. Food Chem Toxicol 2011;49:2862-68.

30. El-Masry TA, Emara AM, Shitany NA. Possible protective effect of propolis against lead induced neurotoxicity in animal model. J Evol Biol Res 2011;3:4-11.

31. Huang Y, Jin M, Pi R, et al. Protective effects of caffeic acid and caffeic acid phenethyl ester against acrolein-induced neurotoxicity in HT22 mouse hippocampal cells. Neurosci Lett 2013;535: 146-51.

32. Nabavi SF, Braidy N, Habtemariam S, et al. Neuroprotective effects of chrysin: from chemistry to medicine. Neurochem Int 2015;90: 224-31. 